\title{
The Characterization of Gene Mutations for Human Glucose Phosphate Isomerase Deficiency Associated with Chronic Hemolytic Anemia
}

\author{
Weiming $\mathbf{X u}$ and Ernest Beutler \\ Department of Molecular and Experimental Medicine, The Scripps Research Institute, La Jolla, California 92037
}

\begin{abstract}
DNA was isolated from four unrelated glucose phosphate isomerase-deficient patients. Seven new mutations in the coding region were found: $247 \mathrm{C} \rightarrow \mathrm{T}, 671 \mathrm{C} \rightarrow \mathrm{T}, 818 \mathrm{G} \rightarrow \mathrm{A}$, $833 \mathrm{C} \rightarrow \mathrm{T}, 1039 \mathrm{C} \rightarrow \mathrm{T}, 1459 \mathrm{C} \rightarrow \mathrm{T}$, and $1483 \mathrm{G} \rightarrow \mathrm{A}$. Three patients were compound heterozygotes, and one patient was a homozygote of $247 \mathrm{C} \rightarrow \mathrm{T} / 247 \mathrm{C} \rightarrow \mathrm{T}$. Six mutations were found to involve highly conserved amino acids of glucose phosphate isomerase, suggesting that these residues are crucial for the maintenance of biological activity. Two polymorphic sites were also identified, $489 \mathrm{~A} \rightarrow \mathrm{G}$ and $1356 \mathrm{G} \rightarrow \mathrm{C}$, which do not produce a change in the amino acid sequence. (J. Clin. Invest. 1994. 94:2326-2329.) Key words: restriction digestion • base substitution • polymorphism • single strand conformation polymorphism • DNA sequencing
\end{abstract}

\section{Introduction}

Glucose phosphate isomerase (GPI, glucose-6-phosphate ketolisomerase, EC 5.3.1.9) ${ }^{1}$ is an enzyme that catalyzes the interconversion of fructose-6-phosphate and glucose-6-phosphate (G6P). GPI plays an essential role in carbohydrate metabolism in all tissues. The substrates of this enzyme, fructose-6-phosphate and G6P, are intermediates in glycolysis and gluconeogenesis, as well as intermediates in the pentose phosphate cycle. In humans, GPI deficiency comprises the third most common hereditary enzyme defect of red cells after G6P dehydrogenase deficiency and pyruvate kinase deficiency and has the typical manifestation of nonspherocytic hemolytic anemia (1-9). It has been reported that severe GPI deficiency can be a cause of hydrops fetalis in humans (10). In addition, neurological impairment has been associated with this disease. GPI deficiency was first described by Baugham et al. (11) in 1967, and by 1990 over 40 unrelated affected families have been characterized by assay of enzyme activity (12). Approximately half of the affected individuals are thought to be homozygotes, while the other half appear to be compound heterozygotes (13).

Address correspondence to Ernest Beutler, Department of Molecular and Experimental Medicine, SBR3, The Scripps Research Institute, 10666 North Torrey Pines Road, La Jolla, CA 92037.

Received for publication 19 August 1994.

1. Abbreviations used in this paper: G6P, glucose-6-phosphate; GPI, glucose phosphate isomerase; SSCP, single strand conformation polymorphism.

J. Clin. Invest.

(C) The American Society for Clinical Investigation, Inc.

0021-9738/94/12/2326/04 \$2.00

Volume 94, December 1994, 2326-2329
GPI may also have a function outside of carbohydrate metabolism. GPI is identical to neuroleukin (14-16), a protein produced by activated $\mathrm{T}$ cells that induces immunoglobin secretion. GPI/neuroleukin, found in large amounts in muscle, brain, heart, and kidneys, has also been shown to support the survival of embryonic spinal neurons, skeletal motor neurons, and sensory neurons (17).

The gene encoding human GPI is located on the long arm of chromosome 19 (18). The 1.9-kb GPI cDNA predicts a protein of 558 residues. The sequence of the $5^{\prime}$ noncoding region, exon 1, intron 1, and exon 2 of the GPI gene has been reported and data suggest that the gene is at least $50 \mathrm{~kb}$ in length (19). Recently, two patients with chronic hemolytic anemia caused by GPI deficiency were shown by reverse transcription PCR to exhibit point mutations (20). One patient (GPILM) was a compound heterozygote of two mutations (475 $\mathrm{G} \rightarrow \mathrm{A} / 1040 \mathrm{G} \rightarrow \mathrm{A}$ ). The other patient (GPI-KS) was homozygous for a $\mathrm{T} \rightarrow \mathrm{C}$ transition at nucleotide (nt) 1574 .

We have recently determined the gene structure and the sequences of the portions of introns flanking its exons (our unpublished data) and now describe seven new mutations causing hemolytic anemia and two polymorphisms in the coding region of the GPI gene.

\section{Methods}

Patients. Four cases of GPI deficiency were diagnosed in patients with chronic hemolytic anemia by assay of erythrocyte enzymes. The clinical data and enzyme activities are summarized in Table I. A complete panel of other red cell enzymes showed normal or increased activities. DNA from peripheral blood leukocytes was isolated by standard methods.

$P C R$ and single strand conformation polymorphism (SSCP) analysis. Scanning for mutations by SSCP analysis was performed on DNA samples from GPI-deficient patients. Intron primer pairs sufficiently distant from the intron/exon borders to avoid the consensus sequence were designed and are listed in Table II. DNA was initially denatured at $98^{\circ} \mathrm{C}$ for $7 \mathrm{~min}$. Each exon was then amplified by PCR using intron primers (25 ng), denatured DNA (200 ng), $\left[\alpha-{ }^{32} \mathrm{P}\right] \mathrm{dATP}(1 \mu \mathrm{Ci}), 0.2$ $\mathrm{mM}$ dNTPs, $1.65 \mathrm{mM} \mathrm{MgCl}_{2}$, and $33.5 \mathrm{mM}$ Tris/HCl, $\mathrm{pH} 8.8$, in a 10$\mu 1$ reaction mix. 30 cycles of $94^{\circ} \mathrm{C}$ for $30 \mathrm{~s}, 58^{\circ} \mathrm{C}$ for $30 \mathrm{~s}$, and $72^{\circ} \mathrm{C}$ for $30 \mathrm{~s}$ were performed in a Thermalcycler (Perkin-Elmer Corp., Norwalk, CT). The PCR product was mixed with $8 \mu \mathrm{l}$ of $95 \%$ formamide, $5 \mathrm{mmol} /$ liter $\mathrm{NaOH}, 0.1 \%$ bromphenol blue, and $0.1 \%$ xylene cyanol. The samples were heated to $95^{\circ} \mathrm{C}$ for $8 \mathrm{~min}$, cooled on ice, and $4 \mu \mathrm{l}$ applied on a $5 \%$ polyacrylamide gel containing $5 \%$ glycerol and 0.5 $\times$ TBE. Electrophoresis was performed at $25 \mathrm{~V} / \mathrm{cm}$ for $6 \mathrm{~h}$ at room temperature.

DNA sequencing and mutation analysis. The samples that demonstrated the presence of a possible mutation by SSCP were subjected to sequence analysis. The double stranded PCR products were purified on quick spin columns (QIAGEN Inc., Chatsworth, CA), and $10 \mathrm{ng}$ of the purified DNA was sequenced by using a cycle sequencing kit (Stratagene, La Jolla, CA) and the original primer pairs. Cycle sequencing was performed using 30 cycles of $95^{\circ} \mathrm{C}$ for $30 \mathrm{~s}, 58^{\circ} \mathrm{C}$ for $30 \mathrm{~s}$, and 
Table I. Clinical Data and Characterization of Gene Mutations for Patients with Hemolytic Anemia Due to GPI Deficiency

\begin{tabular}{llccccccc}
\hline Patient & Ethnic group & Age & Sex & Hb & $\begin{array}{c}\text { Reticulocyte } \\
\text { count }\end{array}$ & $\begin{array}{c}\text { GPI } \\
\text { activity }\end{array}$ & Mutation & Amino acid change \\
\hline & & $y r$ & & $g$ & $\%$ & IU/g/Hb & & \\
1 & White American & $3 / 12$ & $\mathrm{M}$ & 8.7 & 11.2 & 9.82 & $833 \mathrm{C} \rightarrow \mathrm{T} / 1459 \mathrm{C} \rightarrow \mathrm{T}$ & 278 Ser $\rightarrow$ Leu/487 Leu $\rightarrow$ Phe \\
2 & African American & 12 & $\mathrm{M}$ & 10.6 & 17.0 & 15.9 & $818 \mathrm{G} \rightarrow \mathrm{A} / 1039 \mathrm{C} \rightarrow \mathrm{T}$ & $273 \mathrm{Arg} \rightarrow \mathrm{His} / 347 \mathrm{Arg} \rightarrow \mathrm{Cys}$ \\
3 & African American & 8 & $\mathrm{M}$ & 10.3 & 15.0 & 12.25 & $671 \mathrm{C} \rightarrow \mathrm{T} / 1483 \mathrm{G} \rightarrow \mathrm{A}$ & $224 \mathrm{Thr} \rightarrow \mathrm{Met} / 495 \mathrm{Glu} \rightarrow \mathrm{Lys}$ \\
4 & Native American & 4 & $\mathrm{M}$ & 9.8 & 11.0 & 16.44 & $247 \mathrm{C} \rightarrow \mathrm{T} / 247 \mathrm{C} \rightarrow \mathrm{T}$ & $83 \mathrm{Arg} \rightarrow \mathrm{Trp} / 83 \mathrm{Arg} \rightarrow \mathrm{Trp}$ \\
\hline & Normal values & & & $14-17$ & $1.6-2.7$ & $38.8-82.8$ & & \\
\hline
\end{tabular}

$72^{\circ} \mathrm{C}$ for 1 min. Each mutation was verified by sequencing in both directions.

Mutations were also confirmed by endonuclease digestion when the mutation resulted in a change in a restriction site. After PCR, $10 \mu \mathrm{l}$ of the purified DNA was digested with the appropriate enzyme (Table III) for $2 \mathrm{~h}$ and analyzed on a $10 \%$ polyacrylamide gel. To confirm the 1459 $\mathrm{C} \rightarrow \mathrm{T}$ mutation which neither creates nor destroys a restriction site, a mismatched sense primer, 5'CCAAGCTCACACCATTCAAG3', was used in PCR reaction with the normal antisense primer, 5'ATGATGCCCTGAACGAAGATCT3'. PCR with this mismatched primer generates a new HindIII site with wild-type GPI as a template, but does not do so with the 1459 mutant.

The $818 \mathrm{G} \rightarrow \mathrm{A}$ mutation was also confirmed by PCR with a sense primer containing the mutant residue at the 3 ' end, 5'CTAGTGGGTGGGAGGACA 3', and the normal antisense primer, 5'CTGCAACACTGTCTCCC $\overline{A C} 3^{\prime}$. PCR with this primer pair would yield a product of the appropriate size only if the $818 \mathrm{~A}$ mutation was present.

\section{Results}

Table I summarizes the seven new mutations found in four patients with GPI deficiency. All of these mutations, nt 247

Table II. Primer Sequences for Detecting Mutation in the Human GPI Gene

\begin{tabular}{|c|c|c|}
\hline Mutation & Primer pairs & Primer sequences \\
\hline \multicolumn{3}{|l|}{$247 \mathrm{C} \rightarrow \mathrm{T}$} \\
\hline & $E 3 L$ & 5'GACACTTGGGGTGGCCAG3' \\
\hline & $E 3 R$ & 5'TGCCGGCTAACAGTCAG3' \\
\hline \multicolumn{3}{|l|}{$671 \mathrm{C} \rightarrow \mathrm{T}$} \\
\hline & $E 7 L$ & 5'GTCACTGTCACTGACCTGC3' \\
\hline & $E 7 R$ & 5'GCTCTTCCCAGCCCAGAG3' \\
\hline \multicolumn{3}{|l|}{$818 \mathrm{G} \rightarrow \mathrm{A}$} \\
\hline \multicolumn{3}{|l|}{$833 \mathrm{C} \rightarrow \mathrm{T}$} \\
\hline & E10L & 5'GCCCCTGTGCAAGACCAG3' \\
\hline & E10R & 5'CTGCAACACTGTCTCCCAC3' \\
\hline \multicolumn{3}{|l|}{$1039 \mathrm{C} \rightarrow \mathrm{T}$} \\
\hline & $E 12 L$ & 5'CAGAGGCGCGTGTGTTGGT3' \\
\hline & $E 12 R$ & 5'AAAGAGCTCCTGGAGGAGCT3' \\
\hline \multicolumn{3}{|l|}{$1459 \mathrm{C} \rightarrow \mathrm{T}$} \\
\hline & E16L & 5'CAGGACTCTCTTGGAGACAT3' \\
\hline & $E 16 R$ & 5'CAAGCCCATTCCAACCTAC3' \\
\hline \multicolumn{3}{|l|}{$1483 \mathrm{G} \rightarrow \mathrm{A}$} \\
\hline & $E 17 L$ & 5'GTAGGTTGGAATGGGCTTG3' \\
\hline & $E 17 R$ & 5'CGTTGCTACTGAAATCCCTG3' \\
\hline
\end{tabular}

$\mathrm{C} \rightarrow \mathrm{T}$, nt $671 \mathrm{C} \rightarrow \mathrm{T}$, nt $818 \mathrm{G} \rightarrow \mathrm{A}$, nt $833 \mathrm{C} \rightarrow \mathrm{T}$, nt $1039 \mathrm{C} \rightarrow \mathrm{T}$, nt $1459 \mathrm{C} \rightarrow \mathrm{T}$, and nt $1483 \mathrm{G} \rightarrow \mathrm{A}$, were found to be in the coding region. Three of the patients were compound heterozygotes. One of the patients who is of Native American descent is homozygous for $\mathrm{C} \rightarrow \mathrm{T}$ transition at $\mathrm{nt} 247$. The amino acids corresponding to these seven mutant positions in five species are presented in Table IV. Six mutations occur in highly conserved amino acids.

Changes of amino acids may simply be due to polymorphisms present in the normal population. To eliminate this possibility, 28 normal individuals of European American origin

Table III. Verification of Mutations of the Human GPI Gene by Restriction Analysis

\begin{tabular}{llll}
\hline & & \multicolumn{2}{c}{ Size (bp) } \\
\cline { 3 - 4 } \multicolumn{1}{c}{ Mutation } & Enzyme & \multicolumn{1}{c}{ Normal } & \multicolumn{1}{c}{ Mutant } \\
\hline $247 \mathrm{C} \rightarrow \mathrm{T}$ & AciI & $10,79,107$ & 79,117 \\
$671 \mathrm{C} \rightarrow \mathrm{T}$ & BsmAI & $18,96,143$ & 114,143 \\
$818 \mathrm{G} \rightarrow \mathrm{A}$ & HgaI & 90,111 & 201 \\
$833 \mathrm{C} \rightarrow \mathrm{T}$ & MscI & 201 & 79,122 \\
$1039 \mathrm{C} \rightarrow \mathrm{T}$ & AciI & $29,89,117,119$ & $29,89,236$ \\
$1459 \mathrm{C} \rightarrow \mathrm{T}^{*}$ & HindIII & 18,143 & 161 \\
$1483 \mathrm{G} \rightarrow \mathrm{A}$ & Bsp1286 I & $26,32,131$ & 26,163 \\
& & & \\
\hline
\end{tabular}

* $1459 \mathrm{C} \rightarrow \mathrm{T}$ mutation was confirmed by making a mismatched oligonucleotide to create a HindIII site in the wild-type GPI gene (see Methods).

Table IV. Comparison of Amino Acid Residues of GPI among Five Species

\begin{tabular}{llllllll}
\hline & \multicolumn{8}{c}{ Position of human amino acid residue } \\
\cline { 2 - 7 } Organism & 83 & 224 & 273 & 278 & 347 & 487 & 495 \\
\hline T. brucei & Ser & Ser & Arg & Ser & Arg & Leu & Glu \\
Yeast & Ala & Thr & Arg & Ser & Arg & Leu & Glu \\
Mouse & Asn & Thr & Arg & Ser & Arg & Leu & Glu \\
Pig & Arg & Thr & Arg & Ser & Arg & Leu & Glu \\
Human & Arg & Thr & Arg & Ser & Arg & Leu & Glu \\
Mutation & Trp & Met & His & Leu & Cys & Phe & Lys \\
& & & & & & & \\
\hline
\end{tabular}


Table V. Polymorphism at nt 489 in Human GPI Gene and Gene Frequencies

\begin{tabular}{lcccccc}
\hline & & \multicolumn{3}{c}{ Genotype } & & \multicolumn{2}{c}{ Frequencies } \\
\cline { 3 - 5 } \multicolumn{1}{c}{ Ethnic group } & $n$ & $489 \mathrm{~A} / 489 \mathrm{~A}$ & $489 \mathrm{~A} / 489 \mathrm{G}$ & 489G/489G & & $\mathrm{A}$ \\
\hline American White & 40 & 39 & 1 & 0 & 0.987 & 0.013 \\
African American & 39 & 18 & 21 & 0 & 0.731 \\
\end{tabular}

Table VI. Polymorphism at nt 1356 in Human GPI Gene and Gene Frequencies

\begin{tabular}{|c|c|c|c|c|c|c|}
\hline \multirow[b]{2}{*}{ Ethnic group } & \multirow[b]{2}{*}{$n$} & \multicolumn{3}{|c|}{ Genotype } & \multicolumn{2}{|c|}{ Frequencies } \\
\hline & & $1356 \mathrm{G} / 1356 \mathrm{G}$ & $1356 \mathrm{G} / 1356 \mathrm{C}$ & $1356 \mathrm{C} / 1356 \mathrm{C}$ & G & $\mathrm{C}$ \\
\hline American White & 37 & 37 & 0 & 0 & 1.000 & 0.000 \\
\hline African American & 29 & 27 & 2 & 0 & 0.966 & 0.034 \\
\hline
\end{tabular}

were examined for the presence of these 7 base substitutions. The base substitutions found in the GPI-deficient patients were not found in any of these DNA samples.

SSCP analysis and DNA sequencing identified two additional silent base substitutions in a patient with $818 \mathrm{G} \rightarrow \mathrm{A}$ / $1039 \mathrm{C} \rightarrow \mathrm{T}$. The two additional base substitutions, an $\mathrm{A} \rightarrow \mathrm{G}$ substitution at nt 489 and $\mathrm{G} \rightarrow \mathrm{C}$ substitution at nt 1356 , resulted in no change in the deduced amino acid sequence. Both silent mutations were found to be polymorphic sites by performing population studies. The results demonstrated the frequency of the $489 \mathrm{G}$ allele is 0.269 in 78 alleles in the African American population and 0.013 in 80 alleles in the White American population (see Table V). The 1356C polymorphic site was not found in 74 alleles in the White American population and was found with a frequency of 0.034 in 58 alleles in the African American population (see Table VI).

\section{Discussion}

Seven new mutations were identified in the GPI gene. Six of the seven mutations were found to involve highly conserved amino acids. The high degree of conservation of these residues is remarkable since the overall levels of conservation between human and the other species are 57\% identity to Trypanosoma brucei, $58 \%$ identity to yeast, $89 \%$ identity to mouse, and $93 \%$ identity to pig $(14,17,21,22)$. The conservation of these residues and the loss of activity associated with these mutations suggest that they are most likely involved in maintaining the activity of GPI. Interestingly, the $\mathrm{C} \rightarrow \mathrm{T}$ substitution at nt 1039 is adjacent to the known 1040A mutation which affects the identical amino acid, and results in a Arg $\rightarrow$ Cys at residue 347 rather than Arg $\rightarrow$ His by 1040A. This arginine is in close proximity to Asp 342, an important residue localized to the catalytic site in the pig protein (20).

\section{Acknowledgments}

This is manuscript 8806-MEM from The Scripps Research Institute. This study was supported by National Institutes of Health grants HL-
25552 and RR00833 and the Sam Stein and Rose Stein Charitable Trust Fund.

We wish to thank Dr. Julie Katz (University of Texas, Southwestern Medical Center, Dallas, TX), Dr. Brian Berman (Rainbow Babies and Children's Hospital, Cleveland, OH), Dr. Brian J. Cordan (Emory University School of Medicine, Atlanta, GA), and Dr. Mauro Grossi (Children's Hospital, Buffalo, NY) for making samples available to us for study.

\section{References}

1. Blume, K. G., W. Hryniuk, D. Powars, F. Trinidad, C. West, and E. Beutler. 1972. Characterization of two new variants of glucose-phosphate-isomerase deficiency with hereditary nonspherocytic hemolytic anemia. J. Lab. Clin. Med. 79:942-949.

2. Beutler, E., W. H. Sigalove, W. A. Muir, F. Matsumoto, and C. West. 1974. Glucosephosphate-isomerase (GPI) deficiency: GPI Elyria. Ann. Intern. Med. 80:730-732.

3. Sanpitak, N., Y. Supalert, L. Chayutimonkul, and G. Flatz. 1973. Combined erythrocyte phosphohexose isomerase and glucose-6-phosphate dehydrogenase deficiency. Hum. Hered. 23:83-87.

4. Miwa, S., K. Nakashima, S. Oda, E. Oda, N. Matsumoto, H. Ogawa, and Y. Fukumoto. 1973. Glucosephosphate isomerase (GPI) deficiency. Hereditary nonspherocytic hemolytic anemia. Report of the first case found in Japanese. Acta Haematol. Jpn. 36:65-69.

5. Schröter, W., H. H. Koch, B. Wonneberger, and W. Kalinowsky. 1974. Glucose phosphate isomerase deficiency with congenital nonspherocytic hemolytic anemia: a new variant (type Nordhorn). I. Clinical and genetic studies. Pediatr. Res. 8:18-25.

6. Arnold, H., K. G. Blume, and G. W. Löhr. 1974. Glucose phosphate isomerase deficiency with congenital nonspherocytic hemolytic anemia: a new variant (type Nordhorn). II. Purification and biochemical properties of the defective enzyme. Pediatr. Res. 8:26-30.

7. Takegawa, S., H. Fujii, S. Miwa, Y. Ohba, H. Yamauchi, and H. Miyata. 1983. A case of congenital nonspherocytic hemolytic anemia associated with glucosephosphate isomerase (GPI) deficiency-GPI 'Kinki.' Acta Haematol. (Basel). 46:11-17.

8. Merkle, S., and W. Pretsch. 1993. Glucose-6-phosphate isomerase deficiency associated with nonspherocytic hemolytic anemia in the mouse: an animal model for the human disease. Blood. 81:206-213.

9. Eber, S. W., M. Gahr, M. Lakomek, G. Prindull, and W. Schröter. 1986. Clinical symptoms and biochemical properties of three new glucosephosphate isomerase variants. Blut. 53:21-28.

10. Ravindranath, Y., D. E. Paglia, I. Warrier, W. Valentine, M. Nakatani, and R. A. Brockway. 1987. Glucose phosphate isomerase deficiency as a cause of hydrops fetalis. N. Engl. J. Med. 316:258-261.

11. Baugham, M. A., W. N. Valentine, D. E. Paglia, P. O. Ways, E. R. Simon, and Q. B. DeMarsh. 1967. Hereditary hemolytic anemia associated with 
glucosephosphate isomerase (GPI) deficiency. A new enzyme defect of human erythrocytes. Blood. 30:850.

12. Fujii, H., and S. Miwa. 1990. Recent progress in the molecular genetic analysis of erythroenzymopathy. Am. J. Hematol. 34:301-310.

13. Arnold, H. 1979. Inherited glucosephosphate isomerase deficiency. Blut. 39:405-417.

14. Chaput, M., V. Claes, D. Portetelle, I. Cludts, A. Cravador, A. Burny, H Gras, and A. Tartar. 1988. The neurotrophic factor neuroleukin is $90 \%$ homologous with phosphohexose isomerase. Nature (Lond.). 332:454-455.

15. Gurney, M. E. 1988. Reply. Nature (Lond.). 332:457.

16. Faik, P., J. I. H. Walker, A. M. Redmill, and M. J. Morgan. 1988. Mouse glucose-6-phosphate isomerase and neuroleukin have identical 3 ' sequences. $\mathrm{Na}$ ture (Lond.). 332:455-456.

17. Gurney, M. E., S. P. Heinrich, M. R. Lee, and H. S. Yin. 1986. Molecular cloning and expression of neuroleukin, a neurotrophic factor for spinal and sensory neurons. Science (Wash. DC). 234:566-574.
18. McMorris, F. A., T. R. Chen, F. Ricciuti, J. Tischfield, R. Creagan, and F. H. Ruddle. 1973. Chromosome assignments in man of genes for two hexosephosphate isomerase. Science (Wash. DC). 179:1129-1131.

19. Walker, J. I., P. Faik, and M. J. Morgan. 1990. Characterization of the 5' end of the gene for human glucose phosphate isomerase (GPI). Genomics. 7:638643.

20. Walker, J. I. H., D. M. Layton, A. J. Bellingham, M. J. Morgan, and P. Faik. 1993. DNA sequence abnormalities in human glucose-6-phosphate isomerase deficiency. Hum. Mol. Genet. 2:327-329.

21. Marchand, M., U. Kooystra, R. K. Wierenga, A. M. Lambeir, J. V. Beeumen, F. R. Opperdoes, and P. A. M. Michels. 1989. Glucosephosphate isomerase from Trypanosoma brucei. Cloning and characterization of the gene and analysis of the enzyme. Eur. J. Biochem. 184:455-464.

22. Tekamp-Olson, P., R. Najarian, and R. L. Burke. 1988. The isolation, characterization and nucleotide sequence of the phosphoglucoisomerase gene of Saccharomyces cerevisiae. Gene (Amst.). 73:153-161. 